\section{Nitric Oxide and Nitrite Treatments Reduce Ethylene Evolution from Apple Fruit Disks}

\author{
David R. Rudell ${ }^{1}$ and James P. Mattheis ${ }^{2,3}$ \\ U.S. Department of Agriculture, Agricultural Research Service, Tree Fruit \\ Research Laboratory, 1104 N. Western Avenue, Wenatchee, WA 98801-1230
}

Additional index words. Malus sylvestris var. domestica (Borkh.), fresh-cut, nitrogen dioxide, $N$-nitrosoglutathione, sodium nitroprusside

\begin{abstract}
Golden Delicious' apple [Malus sylvestris var. domestica (Borkh.)] cortex disks suspended in solutions containing a nitric oxide (NO) donor $[S$-nitrosoglutathione (GSNO) or sodium nitroprusside (SNP)], $\mathrm{NO}$ gas, or nitrite $\left(\mathrm{KNO}_{2}\right)$ were used to identify impacts of $\mathrm{NO}$ on ethylene production and $\mathrm{NO}_{2}^{-}$on $\mathrm{NO}$ and ethylene production. Treatment with GSNO or SNP reduced ethylene biosynthesis compared with control treatments containing equimolar concentrations of oxidized glutathione (GSSG) or $\mathrm{Na}_{4}(\mathrm{CN})_{6}$ respectively. Apple disk exposure to $\mathrm{NO}$ gas did not impact ethylene production. Treatment with $\mathrm{NO}_{2}^{-}$resulted in increased $\mathrm{NO}$ production and decreased ethylene biosynthesis. Generation of NO increased linearly whereas ethylene generation decreased exponentially with increasing $\mathrm{NO}_{2}^{-}$treatment concentration. NO was enhanced in autoclaved tissue disks treated with $\mathrm{NO}_{2}^{-}$, suggesting that its production is produced at least in part by nonenzymatic means. Although this evidence shows $\mathrm{NO}$ is readily generated in apple fruit disks by $\mathrm{NO}_{2}^{-}$treatment, and ethylene synthesis is reduced by ${ }^{~} \mathrm{NO} / \mathrm{NO}_{2}^{-}$generated in solution, the exact nature of NO generation from $\mathrm{NO}_{2}^{-}$and ethylene synthesis modulation in apple fruit disks remains to be elucidated.
\end{abstract}

The uncharged, gaseous radical nitric oxide ( $\mathrm{NO})$ has an established role in the physiological processes of many organisms. In plants, $\mathrm{NO}$ is implicated in cell damage, signal transduction, and wound response (Neill et al., 2003). NO is involved in the regulation of a wide variety of specific processes including regulation of seed germination (Beligni and Lamattina, 2000), hypocotyl elongation (Beligni and Lamattina, 2000), stomatal aperture (Lum et al., 2002), programmed cell death (Pedroso et al., 2000), xylem differentiation (Gabaldón et al., 2005), plant defense (Delledonne et al., 1998), root development (Pagnussat et al., 2002), regulation of photosynthesis (Takahashi and Yamasaki, 2002), and fruit ripening and senescence (Leshem and Pinchasov, 2000; Leshem et al., 1998; Sozzi et al., 2003).

The free radical nature of $\mathrm{NO}$ contributes to variations in its longevity that are dependent in part on environmental $\mathrm{O}_{2}$, concentration. In aerobic environments, $\mathrm{NO}$ is unstable, reacting with $\mathrm{O}_{2}$ to produce another gaseous free radical, nitrogen dioxide $\left(\mathrm{NO}_{2}\right)$ (Bonner and Stedman, 1996), although the NO half-life is longer than many other biologically significant radical species (Koppenol, 1998). Because NO readily reacts

Received for publication 16 May 2006. Accepted for publication 4 July 2006.

${ }^{1}$ Postdoctoral Research Plant Physiologist.

${ }^{2}$ Research Plant Physiologist.

${ }^{3}$ To whom reprint requests should be addressed; e-mail mattheis@tfrl.ars.usda.gov. with $\mathrm{O}_{2}$, the stability of $\mathrm{NO}$ increases under hypoxic and anoxic conditions (Bonner and Stedman, 1996). In aqueous media, dissolved $\mathrm{NO}_{2}$ typically forms nitrates and nitrites (Bonner and Stedman, 1996). NO can be oxidized or reduced, producing $\mathrm{NO}^{+}$or $\mathrm{NO}^{-}$ (Bonner and Stedman, 1996), species that also exhibit biological activity (Stamler and Feelisch, 1996). Reactions between NO and the reactive oxygen species $\mathrm{O}_{2}{ }^{--}$can produce the highly reactive and potentially damaging species peroxynitrite $\left(\mathrm{OONO}^{-}\right)$(Bonner and Stedman, 1996). Also, unlike many other radical species, $\mathrm{NO}$ can disperse from its cellular origin across membranes to neighboring cells (Neill et al., 2003).

Elucidation of ' $\mathrm{NO}$ synthesis mechanisms in plants is less advanced than in animal systems. In animal systems, a family of FAD/ NADH-containing proteins called nitric oxide synthases catalyze the conversion of L-citrulline to L-arginine and NO (Wendehenne et al., 2001). Although evidence of similar catalytic activity and proteins with analogous structures exists for plants (Guo et al., 2003; Ninnemann and Maier, 1996; Zeidler et al., 2004), additional evidence suggests that other mechanisms of NO production are prevalent in plant systems (Neill et al., 2003; Yamasaki, 2005). Under neutral and alkaline conditions, a reaction catalyzed by nitrate reductase $(\mathrm{NR})$ uses $\mathrm{NAD}(\mathrm{P}) \mathrm{H}$ to reduce $\left(\mathrm{NO}_{2}^{-}\right)$and produce $\mathrm{NO}$ (Dean and Harper, 1988; Yamasaki et al., 1999). This reaction has been demonstrated in plants both in vitro (Yamasaki et al., 1999) and in vivo (Rockel et al., 2002). Other plant enzyme systems also catalyze similar conversions during $\mathrm{O}_{2}$ deprivation when an abundance of $\mathrm{NO}_{2}^{-}$can provide an adequate electron acceptor in lieu of $\mathrm{O}_{2}$ (Neill et al., 2003). Under sufficiently acidic conditions, $\mathrm{HNO}_{2}$ can be reduced to produce $\mathrm{NO}$ by common metabolites including ascorbate (Weitzberg and Lundberg, 1998) and various phenylpropanoids (Bethke et al., 2004; Peri et al., 2005).

Interest in amending horticultural crop storage practices with NO exposure follows reports of decreased NO evolution coincident with increased ethylene production during fruit maturation (Leshem and Pinchasov, 2000; Leshem et al., 1998). Furthermore, exogenous $\mathrm{NO}(g)$ or $\mathrm{NO}$ donor treatment of a variety of agricultural commodities including carnation (Bowyer et al., 2003), broccoli, strawberry, kiwi (Leshem et al., 1998), and pear (Sozzi et al., 2003), purportedly increases storage life.

The objective of the current study was to determine whether NO evolved from donors or supplied as a gas has a role in regulation of ethylene evolution from apple tissue disks.

\section{Materials and Methods}

'Golden Delicious' apple fruit were harvested from a commercial orchard and stored at $0{ }^{\circ} \mathrm{C}$ and $95 \% \mathrm{RH}$ in air for 2 to 4 months. Upon removal from storage, apples were held at $20{ }^{\circ} \mathrm{C}$ for 2 to $3 \mathrm{~d}$. The top and bottom of each apple was removed and a 7-mm brass cork borer was used to excise tubes of cortex tissue. Each tube was sliced into disks $\sim 2$ to $3 \mathrm{~mm}$ thick. About $5 \mathrm{~g}$ of disks were weighed into $50-\mathrm{mL}$ Erlenmeyer flasks, to which a buffered solution containing $5 \mathrm{~mL} 0.1 \mathrm{M}$ 4-morpholineethanesulfonic acid (MES; ( Ph, 6.0), $0.01 \mathrm{M} \mathrm{CaCl}_{2}$, and a specific treatment compound were added. Treatments included 0.01 to $10 \mathrm{~mm} \mathrm{KNO}_{2}, 0.5 \mathrm{~mm} N$-nitrosoglutathione (GSNO), $0.5 \mathrm{~mm}$ oxidized glutathione (GSSG), $0.5 \mathrm{~mm}$ sodium nitroprusside (SNP), and $0.5 \mathrm{~mm} \mathrm{Na}_{4} \mathrm{Fe}(\mathrm{CN})_{6}$. GSNO and SNP are commonly used NO donors, and GSSG and $\mathrm{Na}_{4} \mathrm{Fe}(\mathrm{CN})_{6}$ the respective controls (decomposition products) for these donors. All chemicals were purchased from Sigma-Aldrich (St. Louis, Mo.). Experiments using GSNO, SNP, GSSG, or $\mathrm{Na}_{4} \mathrm{Fe}(\mathrm{CN})_{6}$ were performed in the dark to prevent lightinduced decomposition. Additional cortex disks were autoclaved at $113{ }^{\circ} \mathrm{C}, 68 \mathrm{~N}$, for $13 \mathrm{~min}$ before treatment to evaluate the conversion of $\mathrm{NO}_{2}{ }^{-}$to $\mathrm{NO}$ in nonviable tissue. After introduction of the treatment solution, flasks were left open for at least $30 \mathrm{~min}$, then the head space was evacuated from the flasks using ethylene-free compressed air and the flasks were sealed with a rubber serum stopper. Flask head space was sampled $(0.5 \mathrm{~mL})$ after $30 \mathrm{~min}$ using a $1.0-\mathrm{mL}$ syringe. Ethylene concentration was determined by injecting head space samples into a HewlettPackard 5880 gas chromatograph (Agilent, Palo Alto, Calif.) equipped with a 46-cm (length) $\times 0.32-\mathrm{cm}$ (diameter) glass column 
packed with Porapack PQ (Supelco, Bellefonte, $\mathrm{Pa}$.) and a flame ionization detector. Flow rates for $\mathrm{N}_{2}$ carrier, $\mathrm{H}_{2}$, and compressed air makeup gases were 30,10 , and 100 $\mathrm{mL} \cdot \mathrm{min}^{-1}$ respectively. Oven, injector, and detector temperatures were 60,100 , and $200{ }^{\circ} \mathrm{C}$ respectively. When repeat measurements were made, the serum stopper was removed until the next collection period.

To test the efficacy of NO gas for reducing ethylene evolution, tissue disks were weighed, placed in flasks, and the flasks were sealed as outlined earlier. The flasks were purged with $\mathrm{N}_{2}$ until the head space atmosphere reached $0.5 \mathrm{kPa} \mathrm{O}_{2}$. Flask oxygen concentration was measured using a CheckPoint handheld digital $\mathrm{O}_{2} / \mathrm{CO}_{2}$ meter (PBI Dansensor, Glen Rock, N.J.). NO ( $g$ ) concentration in the flasks was adjusted to $10 \mathrm{uL} \cdot \mathrm{L}^{-1}$ by injecting the gas into the flask head space. Flask NO concentration was verified using a chemiluminescent-based analysis system (Sievers 280i; Sievers, Boulder, Colo.). Head space was drawn into the instrument at 75 $\mathrm{mL} \cdot \mathrm{min}^{-1}$ and the initial (maximum) value recorded. Head space ethylene measurements were made as described previously from samples collected 15, 30, 60, and $75 \mathrm{~min}$ after $\mathrm{NO}$ addition.

All experiments were performed using three or more replications per treatment. Experiments using $\mathrm{NO}$ donors were repeated three times. SE was calculated for the repeated measurements of $\mathrm{C}_{2} \mathrm{H}_{4}$ and $\mathrm{NO}$. Regression analyses using the general linear model was performed using the SAS v.9.0 software package (SAS Institute, Cary, N.C.).

\section{Results and Discussion}

Treatment of 'Golden Delicious' apple cortex disks with $\mathrm{NO}$ donors caused a reduction in ethylene production (Fig. 1). Treatment with GSNO reduced ethylene production within the first $30 \mathrm{~min}$. SNP treatment initially stimulated ethylene production at 45 to $75 \mathrm{~min}$, but production thereafter was lower than that of the control. A previous report indicated the impact of 'NO $(g)$ fumigation treatment on ethylene production was concentration dependent in whole 'Bartlett' pear fruit (Sozzi et al., 2003). Similarly, tomato, lettuce, and pea plant growth was inhibited at high and enhanced at low NO treatment concentrations (Neill et al., 2003). SNP treatment may have induced a similar concentration-dependent response from apple tissue through higher initial release of 'NO or possibly $\mathrm{NO}^{+}$, a species also purportedly generated by SNP (Stamler et al., 1992). Exposure of apple disks to $\mathrm{NO}(g)$ under hypoxic conditions did not alter ethylene production (data not presented). The lack of a NO treatment effect may have been the result of the unstable nature of 'NO gas in air (Bonner and Stedman, 1996), the suppressive effect of hypoxia on apple fruit ethylene production and metabolism, or insufficient accumulation of 'NO in tissue disks compared with treatments during which $\mathrm{NO}$ was generated from aqueous donor compounds.

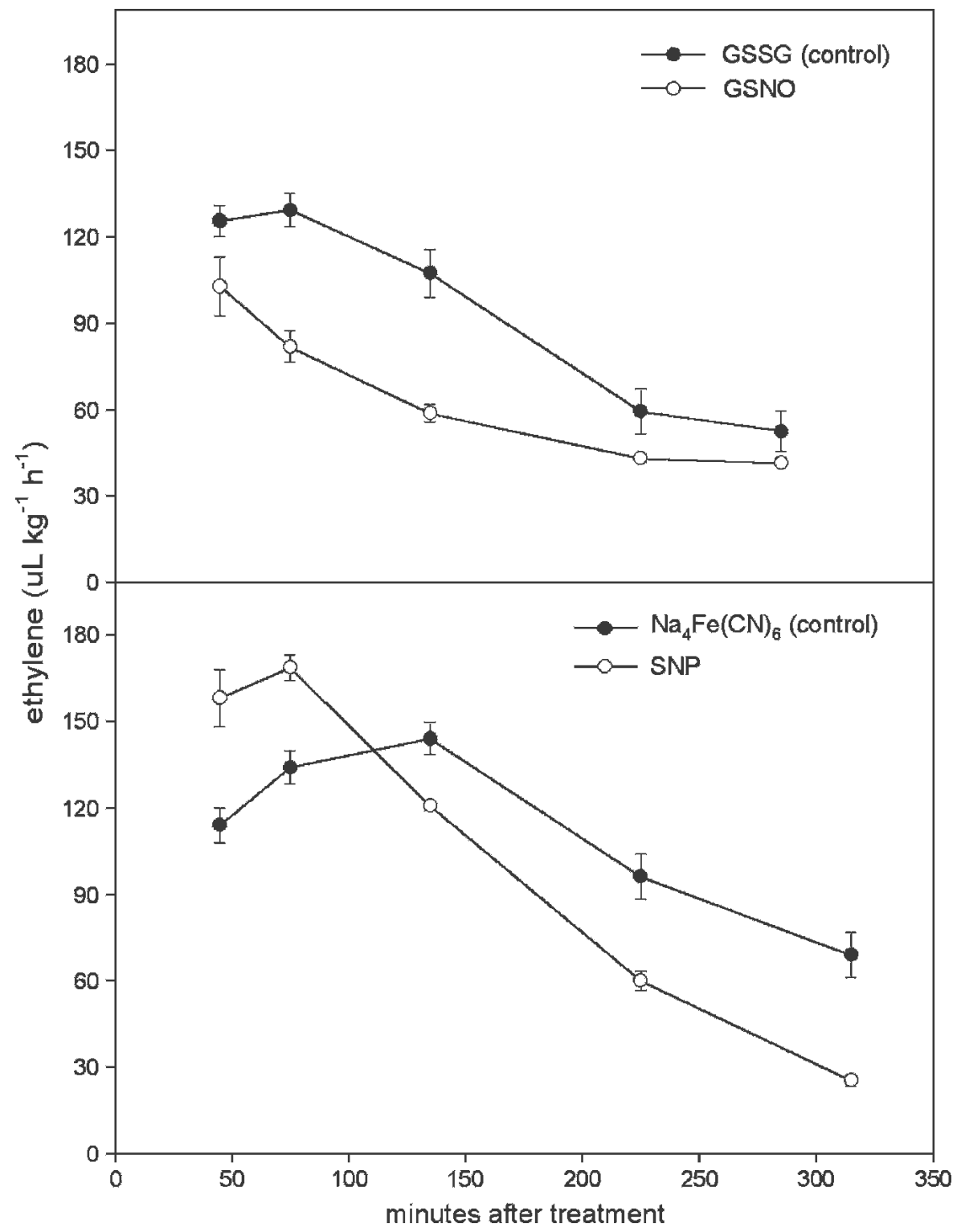

Fig. 1. Ethylene production by 'Golden Delicious' cortex tissue disks during treatment with $500 \mu_{\mathrm{M}}$ of either GSNO and GSSG (control) or SNP and $\mathrm{Na}_{4}(\mathrm{CN})_{6}$ in $0.1 \mathrm{M} \mathrm{MES} \mathrm{(pH,} \mathrm{6.0)} \mathrm{buffer} \mathrm{and} 0.01 \mathrm{M}$ $\mathrm{CaCl}_{2}$. Error bars represent SE $(\mathrm{n}=3)$. SE was smaller than the symbol size where bars are not present.

Nitrite treatment enhanced $\mathrm{NO}$ and decreased ethylene emissions from tissue disks (Fig. 2). Treatment with $1 \mathrm{~mm} \mathrm{NO}_{2}^{-}$resulted in an initial 80-fold increase in NO production that coincided with a 12-fold decrease in ethylene emission by the end of the experiment. $\mathrm{NO}$ production increased with $\mathrm{NO}_{2}{ }^{-}$treatment concentration (Fig. 3A). Maximum inhibition of ethylene emission occurred between $1 \mathrm{mM}$ and $10 \mathrm{mM} \mathrm{NO}_{2}{ }^{-}$ (Fig. 3B). Regression of 'NO production with ethylene production demonstrates a similar inverse relationship between $\mathrm{NO}$ and $\mathrm{C}_{2} \mathrm{H}_{4}$ concentrations (Fig. 3C). Balancing ethylene and $\mathrm{N}_{2}(g)$ or air with increasing levels of 'NO $(g)$ in a gas burret did not affect the ethylene concentration, indicating there is no direct interaction between ethylene and NO (data not presented) that would contribute to the reduced $\mathrm{C}_{2} \mathrm{H}_{4}$ concentrations detected in these experiments. Therefore, reduction of ethylene production with increased NO con- centration appears to occur via an intermediary process contained within the tissue.

The results indicate decreases in ethylene synthesis may have resulted from the presence of increased tissue concentration of $\mathrm{NO}$; however, the nature of the conversion of $\mathrm{NO}_{2}^{-}$to $\mathrm{NO}$ in this system is less clear. Nitrite can be reduced to $\mathrm{NO}$ in reactions catalyzed by various enzymes (Neill et al., 2003), including NR (Yamasaki et al., 1999). Conversely, $\mathrm{NO}_{2}{ }^{-}$can be reduced to $\mathrm{NO}$ in the presence of polyphenols found in apple homogenate (Peri et al., 2005) under acidic conditions where $\mathrm{NO}_{2}{ }^{-}$is converted to $\mathrm{HNO}_{2}$ (Takahama et al., 2003). Autoclaved apple disks produced 19-fold more $\mathrm{NO}$ from $\mathrm{NO}_{2}{ }^{-}$ than control disks, suggesting $\mathrm{NO}$ produced in apple tissue from $\mathrm{NO}_{2}^{-}$may arise at least in part from reactions not requiring metabolic activity. In autoclaved tissue, phenylpropanoids were likely available for interaction with $\mathrm{NO}_{2}{ }^{-}$as a result of decompartmentalization 


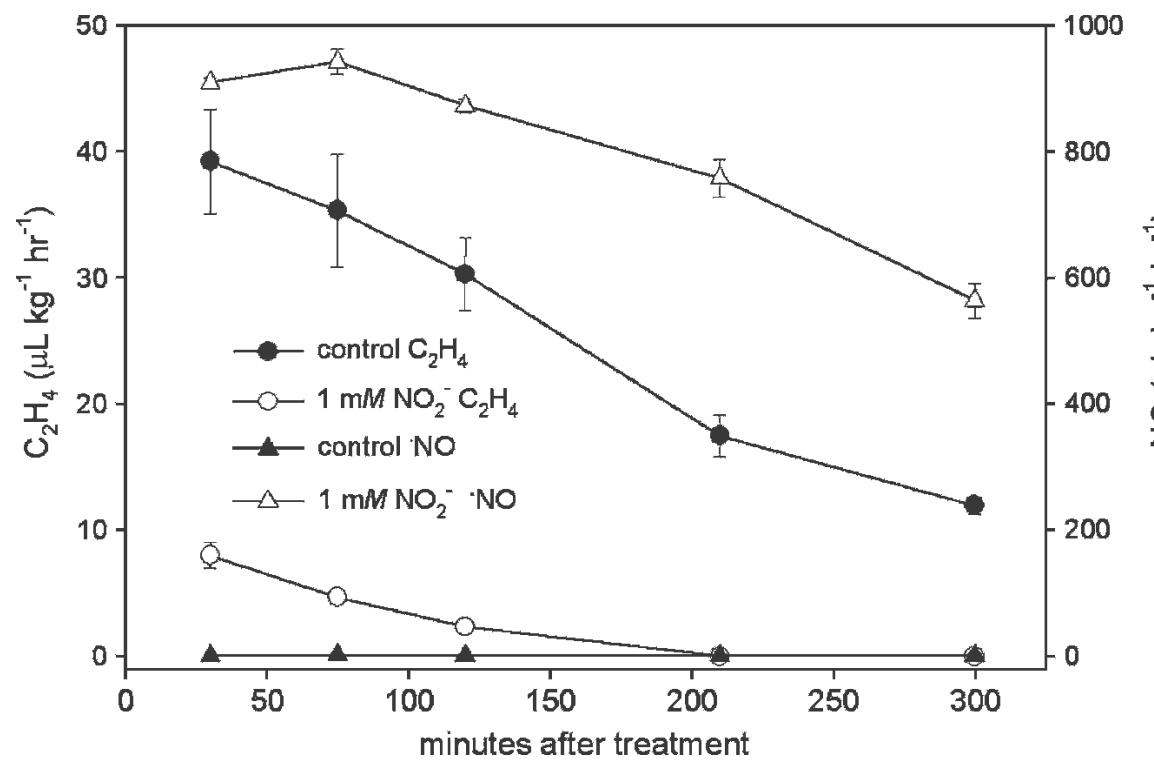

Fig. 2. Ethylene and 'NO production by 'Golden Delicious' cortex tissue disks during treatment with $1 \mathrm{mM}$ $\mathrm{KNO}_{2}$ in $0.1 \mathrm{M}$ MES $(\mathrm{pH}, 6.0)$ buffer and $0.01 \mathrm{M} \mathrm{CaCl}_{2}$. Error bars represent SE error $(\mathrm{n}=3)$. SE was smaller than the symbol size where bars are not present.

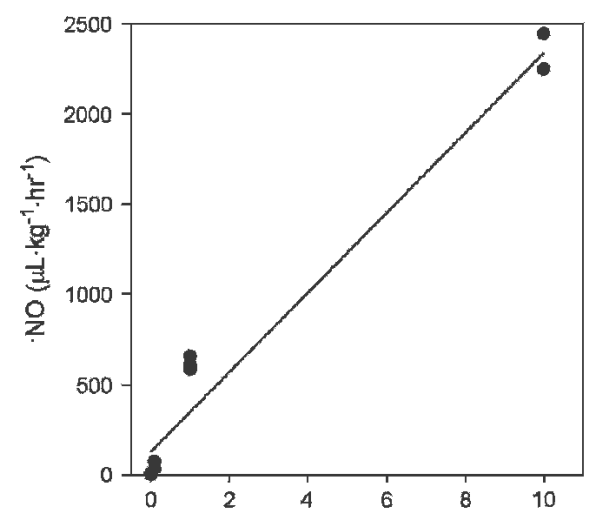

A
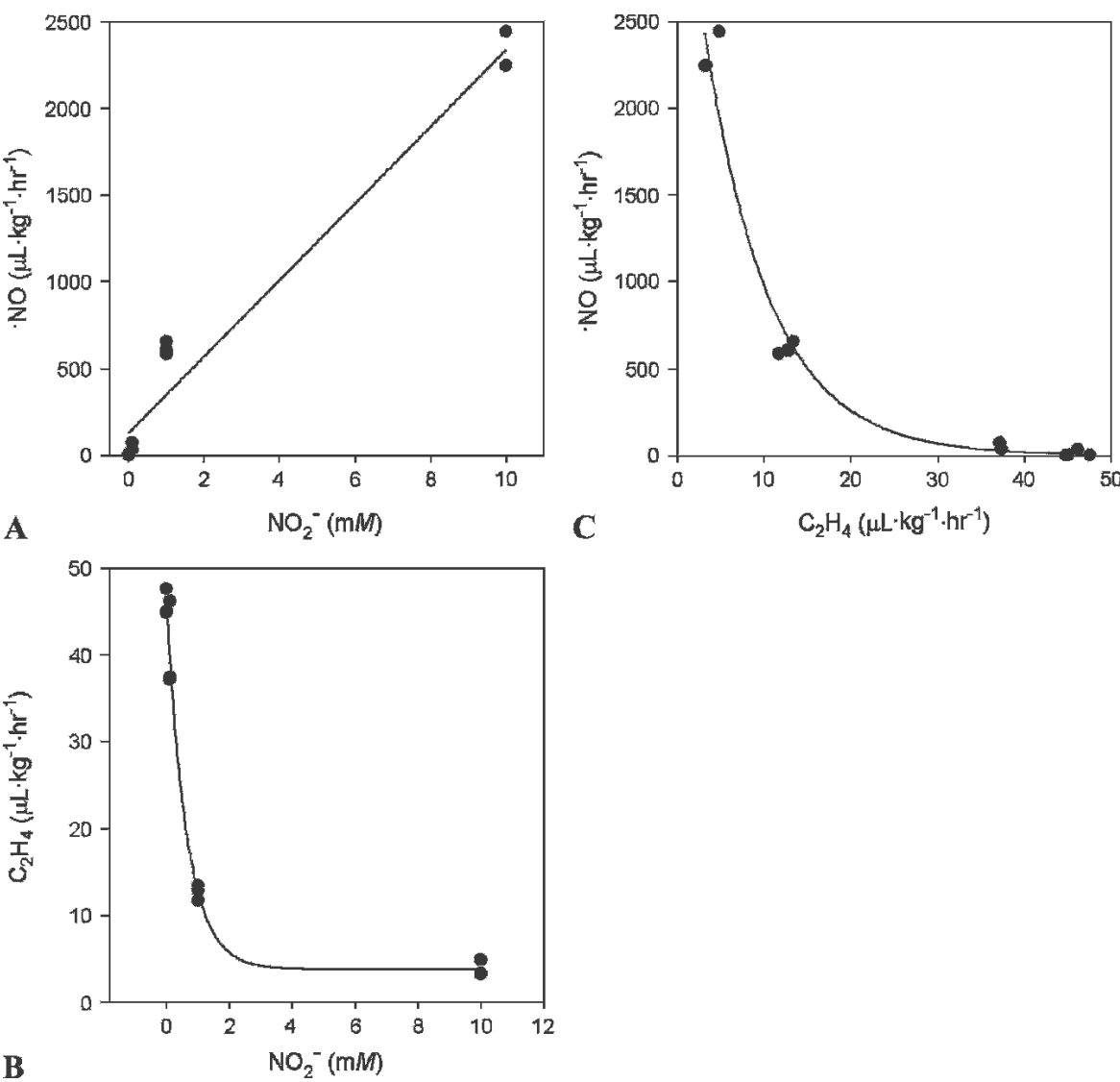

Fig. 3. (A) Linear regression $\left(R^{2}=0.9692, \mathrm{y}=220 \mathrm{x}+132\right)$ of 'NO production by 'Golden Delicious' cortex tissue disks with $\mathrm{NO}_{2}{ }^{-}$treatment concentration. (B) Exponential regression $\left(R^{2}=0.9807, \mathrm{y}=3.75+\right.$ $\left.42.3 \mathrm{e}^{-1.55 x}\right)$ of ethylene production with $\mathrm{NO}_{2}^{-}$treatment concentration. (C) Polynomial $\left(R^{2}=0.9678\right.$, $\mathrm{y}=3720 \mathrm{e}^{-0.133 x}$ ) of ethylene production with $\mathrm{NO}$ production.

resulting from membrane disruption. However, this evidence does not preclude the presence of enzyme-catalyzed reactions of this type in metabolically active apple tissues. NO evolution can be routinely detected from undamaged whole apple fruit (data not presented), warranting further investigation of the mechanisms of NO production.

Exposure of a variety of fruits and floral organs (Bowyer et al., 2003; Leshem et al.,
1998), including a climacteric fruit, 'Bartlett' pear (Pyrus communis) (Sozzi et al., 2003), to NO gas has been reported to promote decreased rates of ripening or senescence. Results of numerous NO fumigation trials using a variety of treatment concentrations and treatment durations, application timing during storage regimes, fruit maturities, and storage periods after treatment using both whole 'Bartlett' pear and other intact apple and pear cultivars in our laboratory have failed to demonstrate consistent efficacy of this treatment for reducing whole apple and pear senescence or for quality maintenance (data not presented). The disparity in ethylene reduction of whole fruit and excised tissue after NO treatment in our studies suggests apple fruit ethylene production systems may be differentially affected by these treatments. For example, our evidence suggests wound ethylene (system 1), stimulated by tissue disruption, may be reduced in the presence of NO, whereas ethylene production resulting from climacteric ripening (system 2) may be impacted less, if at all. The efficiency of $\mathrm{NO}$ treatment for reducing senescence of nonclimacteric commodities (Leshem et al., 1998) may also be consistent with this interpretation.

The current study illustrates reduction of ethylene production using $\mathrm{NO}$ treatment of excised tissue of a climacteric fruit. This treatment may ultimately have utility for extending storage life of fresh-cut fruit. Application of $\mathrm{NO}_{2}^{-}$to tissue disks was highly effective for both enhancing $\mathrm{NO}$ and reducing ethylene levels, indicating that increasing $\mathrm{NO}_{2}^{-}$levels in apple fruit tissue before processing may influence storage life of apple slices while avoiding direct application of $\mathrm{NO}_{2}^{-}$.

\section{Literature Cited}

Beligni, M.V. and L. Lamattina. 2000. Nitric oxide stimulates seed germination and de-etiolation, and inhibits hypocotyl elongation, three lightinducible responses in plants. Planta 210:215221.

Bethke, P.C., M.R. Badger, and R.L. Jones. 2004. Apoplastic synthesis of nitric oxide by plant tissues. Plant Cell 16:332-341.

Bonner, F.T. and G. Stedman. 1996. The chemistry of nitric oxide and redox-related species, p. 318. In: M. Feelisch, and J.S. Stamler (eds.) Methods in nitric oxide research. Wiley, New York.

Bowyer, M.C., R.B.H. Wills, D. Badiyan, and V.V.V. Ku. 2003. Extending the postharves life of carnations with nitric oxide: Comparison of fumigation and in vivo delivery. Postharv. Biol. Technol. 30:281-286.

Dean, J.V. and J.E. Harper. 1988. The conversion of nitrite to nitrogen oxide(s) by the constitutive $\mathrm{NAD}(\mathrm{P}) \mathrm{H}$-nitrate reductase enzyme from soybean. Plant Physiol. 88:389-395.

Delledonne, M., Y. Xia, R.A. Dixon, and C. Lamb. 1998. Nitric oxide functions as a signal in plant disease resistance. Nature 394:585-588.

Gabaldón, C., L.V. Gómez Ros, M.A. Pedreño, and A. Ros Barceló. 2005. Nitric oxide production by the differentiating xylem of Zinnia elegans. New Phytol. 165:121-130.

Guo, F., M. Okamoto, and N.M. Crawford. 2003. Identification of plant nitric oxide synthase 
gene involved in hormonal signaling. Science 302:100-103.

Koppenol, W.H. 1998. The basic chemistry of nitrogen monoxide and peroxynitrite. Free Radic. Biol. Med. 25:385-391.

Leshem, Y.Y., R.B.H. Wills, and V.V.V. Ku. 1998. Evidence for the function of the free radical gas - nitric oxide ( NO) — as an endogenous maturation and senescence regulating factor in higher plants. Plant Physiol. Biochem. 36:825-833.

Leshem, Y.Y. and Y. Pinchasov. 2000. Noninvasive photoacoustic spectroscopic determination of relative endogenous nitric oxide and ethylene content stoichiometry during the ripening of strawberries Fragaria anannasa (Duch.) and avacados Persea americana (Mill.). J. Expt. Bot. 51:1471-1473.

Lum, H.K., T.K.C. Butt, and S.C.L. Lo. 2002. Hydrogen peroxide induces a rapid production of nitric oxide in mung bean (Phaseolus aureus). Nitric Oxide Biol. Chem. 6:205-213.

Neill, S.J., R. Desikan, and J.T. Hancock. 2003. Nitric oxide signaling in plants. New Phytol. 159:11-35.

Ninnemann, H. and J. Maier. 1996. Indications for the occurrence of nitric oxide synthases in fungi and plants and the involvement in photoconidiation of Neurospora crassa. Photochem. Photobiol. 64:393-398.
Pagnussat, G.C., M. Simontacchi, S. Puntarulo, and L. Lamattina. 2002. Nitric oxide is required for root organogenesis. Plant Physiol. 129:954-956.

Pedroso, M.C., J.R. Magalhaes, and D. Durzan. 2000. Nitric oxide induces cell death in Taxus cells. Plant Sci. 157:173-180.

Peri, L., D. Pietraforte, G. Scorza, A. Napolitano, V. Fogliano, and M. Minetti. 2005. Apples increase nitric oxide production by human saliva at acidic $\mathrm{pH}$ of the stomach: A new biological function for polyphenols with a catechol group? Free Radic. Biol. Med. 39:668681.

Rockel, P., F. Strube, A. Rockel, J. Wildt, and W.M. Kaiser. 2002. Regulation of nitric oxide (NO) production by plant nitrate reductase in vivo and in vitro. J. Expt. Bot. 53:103-110.

Sozzi, G.O., G.D. Trinchero, and A.A. Fraschina. 2003. Delayed ripening of 'Bartlett' pears treated with nitric oxide. J. Hort. Sci. Biotechnol. 78:899-903.

Stamler, J.S. and M. Feelisch. 1996. Biochemistry of nitric oxide and redox-related species, p. 1927. In: M. Feelisch, and J.S. Stamler (eds.). Methods in nitric oxide research. Wiley, New York.

Stamler, J.S., D.J. Singel, and J. Loscalzo. 1992. Biochemistry of nitric oxide and its redoxactivated forms. Science 258:1898-1902.
Takahama, U., S. Yamamoto, T. Hiroto, and T. Oniki. 2003. Quercetin-dependent reduction of salivary nitrite to nitric oxide under acidic conditions and interaction between quercetin and ascorbic acid during reduction. J. Agr. Food Chem. 51:6014-6020.

Takahashi, S. and H. Yamasaki. 2002. Reversible inhibition of photophosphorylation in chloroplasts by nitric oxide. FEBS Lett. 512:145-148.

Weitzberg, E. and J. Lundberg. 1998. Nonenzymatic nitric oxide production in humans. Nitric Oxide Biol. Chem. 2:1-7.

Wendehenne, D., A. Pugin, D.F. Klessig, and J. Durner. 2001. Nitric oxide: Comparative synthesis and signaling in animal and plant cells. Trend. Plant Sci. 6:177-183.

Yamasaki, H. 2005. The NO world for plants: Achieving balance in a open system. Plant Cell Environ. 28:78-84.

Yamasaki, H., Y. Sakihama, and S. Takahashi. 1999. An alternative pathway for nitric oxide production in plants: New features of an old enzyme. Trend. Plant Sci. 4:128-129.

Zeidler, D., U. Zähringer, I. Gerber, I. Dubery, T. Hartung, W. Bors, P. Hutzler, and J. Durner. 2004. Innate immunity in Arabidopsis thaliana: Lipopolysaccharides activate nitric oxide synthase (NOS) and induce defense genes. Proc. Natl. Acad. Sci. USA 101:15811-15816. 